\title{
Custodian Rape of a Minor in the Warring Zone of Ezza, Effium Area of Ebonyi State
}

\author{
Ayodele Adegbite Olaleye $^{1^{*}} \mid$ Boniface Nnamdi Ejikeme ${ }^{2}$ | Ede Eziaha Eric Samuel ${ }^{2}$
}

Nwabunike Ekene Okeke ${ }^{2} \mid$ Bartholomew Ifeanyi Olinya $^{2}$ | Emmanuel Olisa Onyekelu ${ }^{3}$

| Charles Nwambeke Edene ${ }^{3} \mid$ John Chinedu Obasi ${ }^{3} \mid$ Amuchechukwu Veronica Nwafor $^{3}$

${ }^{1}$ Professor of Obstetrics and Gynecology, Department of Obstetrics and Gynecology, Alex

Ekwueme Federal University

Teaching Hospital, Abakaliki.

${ }^{2}$ Consultant, Obstetrician Gynecologist, Department of Obstetrics and Gynecology, Alex Ekwueme Federal University Teaching Hospital, Abakaliki.

${ }^{3}$ Senior Registrar, Department of Obstetrics and Gynecology, Alex Ekwueme Federal University Teaching Hospital, Abakaliki.

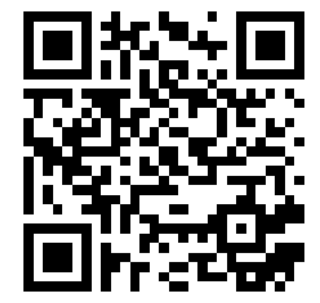

\begin{abstract}
Background : Rape remains a controversial issue with a few victims reporting the experience because of societal perception, prolonged steps in pursuing a case to its logical conclusion of securing conviction, as well as psychological and physical residuals of the experience. Rape occurs globally. It has far reaching physical, psychological, social and emotional effects on the victims which is longstanding, especially in cases of custodian rape as seen in our patient. CASE REPORT: We present a 13 years old secondary school student who presented with severe anemia due to coital laceration, after being raped by a military officer in the warring zones of Effium area of Ebonyi State, Southeastern part of Nigeria. She presented with 3 days history of vaginal bleeding following forceful sexual intercourse by a military officer who was posted to safeguard lives and properties in Effium area of Ebonyi State. At presentation, she was pale, pelvic review showed a $5 \mathrm{~cm}$ long and $3 \mathrm{~cm}$ deep actively bleeding laceration on the 9 'o' clock position of the posterior fornix, extending to the lateral wall of the vaginal. The laceration was repaired in layers in the theatre with vicryl 1 suture and she was transfused with four pints of blood. She was given antibiotics, analgesics and prophylaxis against sexually transmissible infections including human immunodeficiency virus and hepatitis. Patient also had proper psychological supports and counseling in the course of her treatment. The officer involved was said to have absconded from his duty post. CONCLUSION : Custodian rape is prevalent among the vulnerable groups in Nigeria and can lead to life threatening coital laceration. It often leaves the victims helpless, predisposing them to post-traumatic stress disorder, sexually transmitted infections and has far reaching consequences on the future gynecological and obstetrics indices, and of course, can lead to traumatization and frustration of the caregivers. Government needs to do everything possible to reduce the state of insecurity in the country, so as to resettle people back to their natural habitat to curb this menace.
\end{abstract}

Keywords: Custodian, rape, sexual assault, minor, coital laceration, anemia.

Copyright : (C) 2021 The Authors. Published by Medical Editor and Educational Research Publishers Ltd. This is an open access article under the CC BY-NC-ND license

(https://creativecommons.org/licenses/by-nc-nd/4.0/). 


\section{1 | INTRODUCTION}

$\mathrm{F}$ or anybody whose once normal everyday life was suddenly shattered by an act of sexual violence- the trauma, the terror, lingers long after the incident. It lingers. You don't know where to go or who to turn to... and people are more concerned about your attire or alcoholic beverages consumed before the assault, the victim is at fault instead of the attacker ...We still don't condemn sexual assault as loudly as we should. We make excuses, we look the other way... [Laws] won't be enough unless we change the culture that allows assault to happen in the first place.

\section{- President Barack Obama, September 2014}

Nigeria is one of the countries where rape is a major problem. The exponential rise in security challenges has resulted in millions being displaced, living in camps, and the military are required to maintain laws and order. The antecedent consequences include increased cases of violence, social vices, sexual assaults and custodian rape by military personnel ${ }^{1}$.

Rape remains a controversial issue with few victims reporting experience due to societal perception, prolonged steps in pursuing a case to its logical conclusion i.e securing conviction, as well as psychological and physical residuals of the experience ${ }^{1}$. Rape occurs globally. It has far reaching physical, psychological, social and otherwise effect on the victims which is longstanding ${ }^{3}$.

By definition, rape is "the penetration, no matter how slight, of the vagina or anus with any body part or object, or oral penetration by a sex organ of another person, without the consent of the victim ${ }^{4}$." It is an unlawful sexual activity, most often involving sexual intercourse, against the will of the victim through force or the threat of force or with an individual who is incapable of giving legal consent because of minor status, mental illness, mental deficiency, intoxication, unconsciousness, or deception. Sexual assault is a form of sexual violence, and it includes rape (such as forced vaginal, anal or oral penetration or drug facilitated sexual assault), groping, forced kissing, child sexual abuse, or the torture of the person in a sexual manner ${ }^{5,6}$.
There are several variants of sexual assault. Marital rape is a forced coitus or related sexual act within a marital relationship without the consent of the partner $^{5-8}$. Acquaintance rape refer to those sexual assault committed by someone known to the victim e.g. family member, like step relatives or parent, it is also called incest ${ }^{7}$. Date rape is the sexual assault that occurs when forced or unwanted sexual activity occurs in the contest of a dating relationship. Use of alcohol is frequently associated with date rape. Statutory rape refers to sexual intercourse with a female under an age specified by state law (ranging from 14 to 18 years of age); the consent of an adolescent younger than this age is legally irrelevant because she is defined as being incapable of consenting. Child sexual abuse is defined as contact or interaction between a child and an adult when the child is being used for the sexual stimulation of the adult or other person $^{8}$.

Family members, close relatives, neighbors and friends are responsible for majority of incidents ${ }^{6}$. Eighty percent of the victims know their attacker9. An estimate of 700, 000 to 1, 000, 000 American women are sexually assaulted each year8. An incidence of $0.86 \%$ was reported at Aminu Kano University Teaching Hospital ${ }^{9}$ and $2.1 \%$ at Calabar, SouthSouth Nigeria ${ }^{5}$. In South West Nigeria, prevalence of sexual assault is widely varied. Sexual assault accounted for $0.69 \%$ of all female hospital presentation and $5.2 \%$ of all gynecological emergencies in OAUTHC, Ile-Ife ${ }^{10}$. In a study conducted among under-graduates in Ebonyi State University, Abakaliki, South-East Nigeria, an incidence of $19.3 \%$ was obtained $^{11}$. It is a violent crime directed predominantly against women; and fair skinned women are more affected ${ }^{11}$. And usually female between the age brackets of 12-17years are more commonly

Supplementary information The online version of this article (https://doi.org/10.52845/JMRHS/20214-9-6) contains supplementary material, which is available to authorized users.

Corresponding Author: Ayodele Adegbite Olaleye Department of Obstetrics and Gynaecology, Alex Ekwueme Federal University Teaching Hospital, Abakaliki, Nigeria. 
abused $^{10}$.

The predisposing factors are; poor socioeconomic background and polygamous family setting with possibility of poor parental supervision ${ }^{12}$. Other factors are; sex worker, alcohol abuse or other substance abuse, previous history of sexual assault, being incarcerated/institutionalized and mental disablility ${ }^{9}$. In addition, environment and community setting have been associated with increase susceptibility to sexual abuse.

Summary: This is the case of a 13 years old secondary school student who suffered custodian rape at the warring communities of Ezza, Effium Area of Ebonyi State. She presented 3 days after the incident with vaginal bleeding following coital laceration of $5 \mathrm{~cm}$ long and $3 \mathrm{~cm}$ deep on 9 ' 0 ' position of the posterior fornix. She had severe anemia with packed cell volume of $16 \%$ at presentation. The laceration was repaired with vcryl number 1 , she received 4 units of blood, and was treated with antibiotics, and she received prophylactic medications against sexually transmitted infections including hepatitis and HIV. She had adequate psychological support and made uneventful recovery.

\section{2 | CASE REPORT}

Miss OC is a 13 years old JSS 1 student who attained menarche at 11 years of age and presented on day 12 of her menstrual cycle. She resides at Ezza, Effium local government area of Ebonyi State. She is a Christian and a catholic. She was rushed to Gynecology Emergency Unit of our facility by 3 Military Officers with 3 days history of profuse vaginal bleeding following forceful penile vaginal penetrative sexual intercourse by a Military Officer who was deployed to her place of resident to safeguard lives and properties in the area because of ongoing dispute between two clans, in Ezza, Effium, Ohaukwu Local Government Area Ebonyi State. Patient was on her way to the farm when she was called by the assailant. She refused to answer the call but the assailant tipped another girl who is a friend of her, also a 15 years old minor, with \#500.00 to help convince her. Her friend later tricked her into the new location where the Military Officer was, waiting for them. Thereafter, the Military Officer attempted to coerce her with \#1000.00 to allow him have sexual intercourse with him. She declined even when the officer doubled the amount to \#2000.00. This prompted the military man to signal to her friend to leave them alone. She attempted to follow her friend after which the Military Officer dragged her into the nearby hurt and had forceful vaginal intercourse with her, after beating her into submission and threatened to take her life. Immediately after the intercourse, she started bleeding profusely and the Military Officer ran away. The other Military Officers later came into the hurt and rushed her to the Military Clinic where she was accessed and vaginal packing was applied to reduce the bleeding. This reduced the bleeding a bit. She was given oral antibiotics and analgesics. However, attempts to remove the vulva pad after 12 hours resulted in further bleeding and the pad was reapplied. Further attempts to remove the pads at 24, and 48 hours after its application resulted into further bleeding after which she started complaining of dizziness and lightheadedness. This necessitated the decision to bring her to our facility for further care. Patient has already taken her bath, changed her clothes and brushed her mouth prior to presentation. There was no history of prior sexual intercourse. She complained of pain on her neck pain and left arm. She also had minor bruises on her left thumb, left middle finger and left big toe. She attained menarche at 11 years and had 5 days regular flow in a 30 days cycle. There was no history of menorrhagia or dysmenorrhea and yet to attain coitarche. She is the third child in a family of 8 with 5 siblings. Both parents are farmers with no formal education. She has never tasted alcohol or used tobacco in any form.

On examination, we observed a fair skinned young girl, anxious looking and depressed, afebrile, anicteric, acyanosed and no pedal edema but bruises on the left thumb, left middle finger and left toe. Her respiratory rate was 38 cycles per minute and vesicular breath sounds were heard on auscultation of chest. Her pulse rate was 110 beats per minute, small volume, blood pressure was $80 / 40 \mathrm{mmHg}$, heart sounds I \& II only were heard. There was no area of tenderness on abdominal palpation and no organ enlargement. Kidneys were not ballotable. Pelvic examina- 
tion revealed blood smeared vulva and vagina. Minor bruises on the posterior fourchette, about $150 \mathrm{mls}$ of blood clots were evacuated from the vagina, there was an actively bleeding posterior fornix laceration, extending to the lateral wall of the vaginal. The bleeding edges were clamped with sponge holding forceps and patients was worked up for examination under anaesthesia and repair of coital laceration.

The patient, her parents and the Military Officers were counseled on the findings and treatment options. Consent for treatment, investigation and surgery was obtained. The hospital police doctor and legal department were informed, result of Laboratory findings were packed cell volume of $16 \%$, white cell count was $6.1 \times 10^{6} / \mathrm{ml}$, the differentials were within normal limits, urinalysis showed no abnormality, retroviral screening was negative, hepatitis B surface antigen and hepatitis c virus were negative, venereal disease research laboratory screening was negative, pregnancy test was negative, 4 units of blood were grouped and cross matched for her. She was given stat dose of intravenous ceftriaxone $1 \mathrm{~g}$ and metronidazole $500 \mathrm{mg}$ before the repair. The repair was done in the theatre under general anaesthesia. Intra-operative findings were blood smeared vulva and vaginal, bruises on the posterior fourchette, a transverse laceration at 9 ' 0 ' clock position of the posterior fornix extending to the left lateral wall of the vaginal, about $5 \mathrm{~cm}$ long and $3 \mathrm{~cm}$ deep. Cervix was normal. Laceration was repaired with delayed absorbable vicryl 1 suture continuously and the procedure was tolerated. Vaginal was packed with gauze. She had a pint of blood transfused intra-operatively and was admitted into Gynecology ward. She was placed on parenteral ceftriaxone $1 \mathrm{~g}$ 12 hourly for 48 hours and metronidazole $500 \mathrm{mg}$ 8 hourly for 48 hours. She was given stat dose of levonorgestrel $1.5 \mathrm{mg}$. Further 3 units of blood were given on the ward. She was reviewed by the physicians and was given hepatitis B immunoglobulin, she also commenced prophylaxis against HIV using combination of oral Tenofovir $300 \mathrm{mg}$ daily, Emtricitabine 200mg daily and Dolutegravir 50mg daily, all for 28 days. Psychologists and Medical Social Workers were invited to support the patient and the parents psychologically. Hospital legal team is presently handling the case.
She made good progress. Post transfusion packed cell volume was $31 \%$ on day 5 post operation. She was placed on cefpodoxime $200 \mathrm{mg}$ twice a day and oral metronidazole $400 \mathrm{mg}$ thrice a day for 7 days after completing parenteral antibiotics, she also received oral doxycycline $100 \mathrm{mg}$ twice a day for 10 days. She was discharged from hospital on day 6 post operation. She was seen two weeks after the discharge and was very cheerful with no complaints. The assailant was not found. She was compliant with her medications and keeping her Psychology Clinic appointments. Her pregnancy test was negative. She was given another 4 weeks appointment. During this appointment she had no physical or psychological complaints. She had seen her menses and the flow was normal. She had second dose of hepatitis B immunoglobulin 4 weeks after the first and the third dose 6 months after the first, her retroviral screening done at 6 weeks, 3 months and 6 months post exposure were negative. She was properly counseled on how to prevent recurrence and had further psychological supports. She was then discharged from clinic.

Her girlfriend never showed up in the hospital throughout her stay. The parents are less concerned about prosecution and they are more concerned about their daughter's life. They even refused to cooperate with the hospital legal department.

\section{3 | DISCUSSION}

Rape and coital laceration cases in our environment have persistently remained unreported as victims are scared of the resultant societal stigma/controversial attention that come with $\mathrm{it}^{2,13}$. Also situations in which the assailant has stronger social and financial advantages over the victim, most rape cases may be unreported. Rape often affect young lady with poor socioeconomic background and ladies that are raised in polygamous family setting with possibility of poor parental supervision ${ }^{12}$. Family members, close relatives, neighbors and friends are responsible for majority of incidents ${ }^{7}$. Rape is the commonest etiological factor for coital vaginal injuries, followed by nulliparity ${ }^{13}$. A minor that was raped and suffered 
coital laceration leading to severe anemia will definitely have multi-traumatic experience or develop posttraumatic stress disorder. This is worsened by the fact that the assailant is someone that is entrusted to protect her from such incident. The fact that she was allowed to bleed continuously for close to 72 hours before she could access proper care is a reflection of our poor state of health care, care givers and referral chain.

The incidence of rape is rising worldwide with annual incidence of up to $0.96 \%$ and a steady yearly rise in incidence has been reported ${ }^{2}$. An incidence of $0.86 \%$ was reported at Aminu Kano University Teaching Hospital ${ }^{9}$ and $2.1 \%$ at Calabar, SouthSouth Nigeria ${ }^{5}$. In South West Nigeria, prevalence of sexual assault is widely varied. Sexual assault accounted for $0.69 \%$ of all female hospital presentation and $5.2 \%$ of all gynecological emergencies at OAUTHC, Ile-Ife ${ }^{10}$. In a study conducted among under-graduates in Ebonyi State University, Abakaliki, South-East Nigeria, an incidence of $19.3 \%$ was obtained $^{11}$. Incidence of coital trauma also varied widely. The incidence of $0.34 \%$ was recorded in Maiduguri $^{14}$ and $0.7 \%$ in Abraka, Edo State ${ }^{15}$. With rising incidence of insecurity, communal clashes, wars and conflicts, the incidence of custodian rape will continue to increase.

Rape has been described as a violent crime directed predominantly against women; and fair skinned women like our patient are more affected ${ }^{11}$. A young lady with poor socioeconomic background like our patient is at risk of being sexually assaulted ${ }^{12}$. Also at age 13 years, she falls in between the age brackets of 12-17years that are more commonly affected ${ }^{10}$ Coital laceration can complicate rape especially in victims with first sexual intercourse like our patient, and those with prolonged abstinence. The sexual positions such as dorsal position also increased the risk of coital injury. Others include rough coitus, penovaginal disproportion, use of aphrodisiacs as vaginal lubricant and inadequate emotional and physical preparation of women for sexual intercourse ${ }^{13,16}$. This was the first sexual experience of our patient and she had a rough coitus without foreplay with suspicion of peno-vaginal disproportion. Also, inadequate emotional and physical foreplay as seen in our patient has been attributed increased risk of coital laceration $^{13}$, and especially in rape cases. Threat of violence and physical force were the common methods for overcoming the rape victims ${ }^{16}$, as seen in the index patient.

Management of rape victims involves treating the physical injuries sustained during the assault, prophylactic medical treatment of sexually transmitted infection especially chlamydial, gonoccocal and trichomonal infections by using start dose of intravenous ceftriaxone, with oral metronidazole and doxycycline $^{8}$. Doxycycline is also effective against syphilis. The lower vagina was the most common site of coital injury ${ }^{13}$. Vaginal bleeding was the commonest mode of presentation of coital laceration and hypovolaemic shock is the most common complication $^{13}$ of coital injuries. As a result, our patient was resuscitated with intravenous fluid, had blood transfusion and surgical repair of the laceration, which involved examination under anaesthesia and repair of coital laceration at the theatre. Hepatitis $\mathrm{B}$ immunoglobulin should be given at 0,1 and 6 months of exposure, as done for our patient. Emergency contraception was offered as prophylaxis against pregnancy, as the risk of pregnancy after sexual assault has been estimated to be $2-4 \%$ in victims who are not using some form of contraception at the time of assault ${ }^{8}$. Also at presentation, our patient was anxious and depressed, as a result, she was supported psychologically and properly counseled by both the managing gynecology team and the invited Clinical Psychologists. She also had Anti-retroviral agents as prophylaxis against HIV. She was properly followed up and properly supported.17

Hypovolemic shock is a common complication of coital laceration and both coital injury and rape has serious effect on the social and psychological wellbeing of the victim. A "rape trauma" syndrome often occurs after sexual assault ${ }^{8,18}$. The initial response (acute phase) may last for hours or days and it is characterized by a distortion or paralysis of individual's coping mechanism as was seen in our patient who was depressed and anxious at presentation. The initial outwards responses vary from loss of emotional control (crying, uncontrolled anger) to an unnatural calmness and detachment. It also involves shock, numbness, withdrawal and denial. The next phase (delayed phase) occurs several months to years 
after the sexual assault and it is characterized by chronic anxiety, feeling of vulnerability, loss of control and self-blame. Long term reaction include anxiety, nightmares, flashbacks, catastrophic fantasies, feeling of alienation and isolation, sexual dysfunction, psychological distress, mistrust of others, phobias, depression, hostility and somatic symptoms. Some often find it difficult to re-establish emotional and sexual relationships with spouse. Post-traumatic stress disorder is a common long term sequel of sexual assault characterized by psychic numbing, intrusive re-experiencing of the trauma, and avoidance of stimuli associated with the trauma and intensive psychological distress. Physical injury occurs in $33 \%$ of victims ${ }^{10}$. Although, the physical injuries are usually minor some may require major surgical repair ${ }^{8,10}$, as seen in the patient under review.

Sexual harassment and assault may be prevented at primary level through public education programs at secondary schools, colleges and work-places ${ }^{19}$. Part of the programs put in place in the developed world to help in prevention of violent act and sexual assault against women include; The men's and woman's program called "One in Four" in the United States, Bring in the Bystander, Mentor of Violence Prevention (aMVP), Green Dot programme and 'Its on us' introduced in 2014 by Former President Barack Obama and Former Vice President Joe Biden ${ }^{20}$. More recently, Trauma-informed prevention was introduced in colleges to help promotes empowerment of sexual assault survivors and help survivors moving forward, including better peer relationships, academic progress, as well as reducing the likelihood of engaging in subsequent risky alcohol use, and poor mental health ${ }^{21}$. In Nigeria, personnel training, protocol development, provision of rape kits and free treatment of sexual assault survivors have been recommended. Public enlightenment on preventive strategies based on the observed periodicity and age patterns has also been suggested ${ }^{10,22}$. Education on improving literacy level of the populace is an important tool because trapped as they are, like the parents of our patient, the solution to their ignorance is education. Legislation and proper implementation of laws to punish culprits like the offending Military officer involved in this case, as well as proper rehabilitation and compensation of victims will go a long way in reducing these cases and bringing some succor to the victims' family. In the rural setting, as was in the case of our patient, sexual assault can be prevented through creation of awareness and public enlightenment of adolescents and young adult on sexual assault. Emphasis should be laid on the young adults in the vulnerable age group (12 to 17years) like the index case to avoid staying alone in secluded places. Also, women empowerment and education together with melting out severe punishment on the culprits will go a long way in reducing the incidence of sexual assault.

In conclusion, sexual assault is a very distressing condition that may have serious emotional and psychological effects on both the victim and his/her relatives. Efforts should be directed towards prevention through girl child education, gender equality and eradiation of poverty. Victims need treatment against possible sexually transmitted infections and adequate psychological support to prevent any posttraumatic psychological disorders. Strict legislatures need to be enacted against sexual assault. By and large, with proper support and adequate management of victims, final outcomes are often encouraging. Rising insecurity has contributed to increasing cases of sexual assault. Government has a role to play in securing its citizens and proper education of members of military and para-military organizations will help to stem this menace.

\section{DECLARATIONS}

\section{Author contribution statement:}

All authors listed have significantly contributed to the investigation, development and writing of this paper.

\section{Funding statement:}

This study received no specific grant from funding agencies in the public, commercial, or not-for-profit sectors.

\section{Competing interest statement:}

The authors declare that there was no conflict of interest.

\section{Additional information}

No additional information is available for this paper.

\section{Acknowledgements :}


We would like to offer our special thanks to our patient who allowed us to present this study for the benefit of patients across the world.

\section{References}

1. Freedom House. Freedom in the World 2011: The Annual Survey of Political Rights and Civil Liberties (Freedom in the World: The Annual Survey of Political Rights \& Civil Liberties (Paperback)). Rowman and Littlefield Publishers, 1st Edition, Kindle Edition. 2011; pp 304-495. ISBN: 978-1442209947. Available (a) https://www.amazon.com/Freedom-World2011-Political-Liberties-ebook/dp/B00915KB $8 \mathrm{G}$

2. Idoko CA, Nwobodo ED, Idoko CI. Trends in rape cases in a Nigerian state.

3. Sexual Violence-World Health Organization. Available@: http://www.who.int/violence_inj ury_prevention/violence/global_campaign/.../c hap6.pdf.

4. Barstow, Anne L. "Rape". Encyclopedia Britannica, 19 Nov. 2020, https://www.britanni ca.com/topic/rape-crime. \{Accessed 17 May 2021.\}

5. Ezechi OC, Musa ZA, David AN, Wapmuk AE, Gbajabiamila TA, Idigbe IE. et al. Trends and patterns of sexual assaults in Lagos southwestern Nigeria. The Pan Afr Med J. 2016; 24 : 261.

6. "Sexual Assault: National Training Standards for Sexual Assault Medical Forensic Examination". Department of Justice/justice. Available at: www.justice.gov/ovw/sexual-assault. Retrieved August 2nd, 2018. [Accessed on May 17, 2021).

7. Sodipo OO, Adedokun A, Adejumo AO, Oibamoyo O. The pattern and characteristics of sexual assault perpetrators and survivors managed at a sexual assault referral centre in Lagos. Afr J Prim Health Care Fam Med. 2018; 10(1): 1727.
8. Michael C, Jessica S, Vivian PH. Domestic Violence \& Sexual Assault. In: Current Diagnosis and Treatment, Textbook of Obstetrics and Gynecology, 11th Edition. The McGraw-Hill Companies. 2013; 971-78.

9. Akinade E, Adewuyi T, Sulaiman A. Sociolegal factors that influence the perpetuation of rape in Nigeria. J Procedia - Social and Behavioral Sciences. 2010; 5: 1760-4

10. Badejoko OO, Anyabolu HC, Badejoko BO, Ijarotimi AO, Kuti O, Adejuyigbe EA. Sexual assault in Ile-Ife, Nigeria. Niger Med J. 2014; 55:254-9.

11. Umeora OUJ, Obunna JA. A Survey into the Prevalence and Pattern of Rape in a Nigerian Tertiary Institution. Int J of Innovation and Sci Res. 2015; 13(2): 349-353.

12. UN Women. "Facts and figures: Ending violence against women". Available @ http://ww w.UNWomen.org. UN Women. Retrieved 14 September 2018. (Accessed 17th May, 2021).

13. Oriji PC, Omietimi JE, Allagoa D, Sominyai IRC, Adeniran A, Ikiba P, et al. Coital laceration in shock: A case report. Yen Med J. 2019;1(1):49-51.

14. Mairiga A, Umaru I, Babagana B and Geidam A. Coital trauma as seen at the University of Maiduguri teaching Hospital, Maiduguri. Borno Med J. 2013; 10(1):25 - 29.

15. Omo-Aghoja LO, Ovbagbedia O, Feyi-Waboso $\mathrm{P}$, Okonofua FE. Coitally related injury of the female genital tract in a Nigerian urban: A 5-year review. Niger Postgrad Med J. 2009; 16(1):59-63.

16. Fletcher H, Bambury I, Williams M. Postcoital posterior fornix perforation with peritonitis and haemoperitoneum. Int J Surg Case Rep. 2013;4(2):153-155.

17. Ezechi OC, Adesolamusa Z, David AN, Wapmuk AE, Gbajabiamila TA, Eugeniaidigbe I, et al. 
18. Akinade E, Adewuyi T, Sulaiman A. Sociolegal factors that influence the perpetuation of rape in Nigeria. J Procedia - Social and Behavioral Sciences. 2010; 5: 1760-4.

19. Eze UO. Prevention of Sexual Assault In Nigeria. Ann Ibd. Pg Med. 2013; 11(2): 65-70.

20. Somanader T. "White House announces college-campus sexual assault awareness campaign". Available at: https://www.whiteh ouse.gov $>2014 / 09 / 19$. Retrieved 19 September 2014. [Accessed May 18, 2021].

21. McCualey HL, Casler AW. College Sexual Assault: A Call for Trauma-Informed Prevention. J Adolesc Health. 2015; 56 (6): 584-585.
22. Badejoko OO, Anyabolu HC, Badejoko BO, Ijarotimi AO, Kuti O, Adejuyigbe EA. Sexual assault in Ile-Ife, Nigeria. Niger Med J. 2014; 55:254-9.

How to cite this article: Olaleye A.A., Ejikeme B.N., Samuel E.E.E., Okeke N.E., Olinya B.I., Onyekelu E.O., Nwambeke Edene C., Obasi J.C., Nwafor A.V. Custodian Rape of a Minor in the Warring Zone of Ezza, Effium Area of Ebonyi State. Journal of Medical Research and Health Sciences. 2021;1468-1475. https:// doi.org /10.52845/JMRHS/2021-4-9-6 